\title{
PEMANFAATAN LIMBAH PLASTIK SEBAGAI MATERIAL TAMBAHAN PADA KONSTRUKSI TIMBUNAN RINGAN
}

\author{
Gerard Aponno $^{1}$, Yunaefi ${ }^{2}$, Moch.Sholeh ${ }^{3}$ \\ 1,2,3 Dosen Jurusan Teknik Sipil Politeknik Negeri Malang \\ 1'gappono@gmail.com, ${ }^{2}$ yyunaefi@yahoo.com, ${ }^{3}$ moch.sholeh@gmail.com \\ (Artikel diterima: Februari 2020, direvisi: April 2020, diterima untuk terbit: Juli 2020)
}

\begin{abstract}
Abstrak - Permasalahan terkait limbah saat ini telah menjadi isu yang mendapat perhatian serius baik secara nasional bahkan internasional. Berbagai macam limbah dihasilkan dari setiap sektor kehidupan, salah satunya berupa limbah plastik. Pada bidang konstruksi, limbah plastik diharapkan bisa menjadi salah satu alternatif material untuk timbunan ringan karena berat volume plastik yang lebih ringan daripada tanah. Tujuan penelitian ini yaitu menganalisis perubahan nilai CBR akibat penambahan limbah plastik, dan mengkaji pengaplikasian sebagai material timbunan ringan pada konstruksi jalan. Penelitian ini dilakukan di laboratorium dengan menggunakan butiran limbah Poly Propylene (PP) yang ditambahkan pada tanah dengan persentase sebesar $0 \%, 12,5 \%, 22,5 \%$, dan 32,5\% terhadap berat isi kering tanah. Hasil penelitian menunjukkan nilai CBR standard berturut-turut sesuai komposisi dalam kondisi unsoaked yaitu sebesar 17,73 \%, 13,35 \%, 9,66 \%, dan 7,76 \%. Pada kondisi soaked nilai yang dihasilkan sebesar 6,86\%, 5,13\%, 3,89\%, dan 2,69\%. Ditinjau dari pengujian CBR modified, nilai CBR yang dihasilkan untuk kondisi unsoaked yaitu 22,63\%, 18,31\%, 15,67 \%, dan 10,93 \%. Pada kondisi soaked nilai CBR sebesar $11,97 \%, 10,49 \%, 9,04 \%$, dan 8,14\%. Secara keseluruhan limbah plastik yang dicampurkan pada tanah menyebabkan penurunan nilai CBR
\end{abstract}

Kata kunci: limbah plastik, CBR, timbunan ringan.

\section{Pendahuluan}

Isu yang masih belum mendapatkan penyelesaian dengan optimal yakni terkait permasalahan sampah atau limbah. Salah satu limbah yang belum mendapat penanganan dengan maksimal yaitu limbah plastik. Kementerian Lingkungan Hidup dan Kehutanan (KLHK) menilai persoalan sampah sudah meresahkan. Indonesia bahkan masuk dalam peringkat kedua di dunia sebagai penghasil sampah plastik ke Laut setelah Tiongkok. Berbagai macam limbah dihasilkan oleh setiap sektor kehidupan, termasuk diantaranya yaitu proses konstruksi yang juga memiliki andil dalam menyumbang pertambahan jumlah limbah. Berbagai macam cara untuk mengolah limbah telah dilakukan namun masih belum menampakkan hasil yang terlalu signifikan. Hal itu bisa dilihat dari keberadaan limbah yang masih sangat melimpah. Limbah dapat menjadi salah satu penyebab kegagalan perencanaan konstruksi. Contoh konkritnya yaitu bila ada limbah yang menyumbat drainase jalan. Air yang harusnya ditampung drainase akan melimpas ke jalan yang nantinya akan merubah struktur jalan tersebut.

Pembangunan infrastruktur secara besar-besaran terjadi di negara Indonesia. Salah satu hal yang harus diperhatikan dalam proses pembangunan yaitu tentang kondisi tanah yang ada. Pembangunan ini sudah pasti menuai berbagai masalah, salah satunya terkait penurunan permukaan tanah. Pada dasarnya penurunan permukaan tanah sudah direncanakan pada proses konstruksi tersebut. Namun pada kenyataannya, seringkali terjadi permasalahan yaitu penurunan yang tidak sesuai perencanaan. Banyak upaya untuk mengatasi masalah penurunan tersebut. Berbagai metode dihasilkan untuk menanggulangi permasalahan yang terjadi. Metode yang telah diterapkan antara lain metode statik, metode dinamik, dan metode kimiawi. Metode kimiawi atau stabilisasi kimiawi yang sering kali dilakukan yaitu jet grouting dan deep soil mixing (Hidayat \& Suhendra, 2011).
Pada penelitian ini, permasalahan yang dibahas tentang timbunan tanah. Aspek yang dikaji dalam timbunan tanah yaitu terkait penurunan permukaan tanah. Pengkajian ini memfokuskan pada alternatif penggunaan timbunan dengan material ringan untuk meminimalisir penurunan permukaan tanah yang akan terjadi. Salah satu upaya yang dilakukan untuk merealisasikan hal tersebut yaitu penggunaan limbah plastik sebagai bahan alternatif pada timbunan. Limbah plastik ini akan dicampurkan pada agregat halus guna mendapatkan timbunan yang lebih ringan dibandingkan timbunan pada umumnya. Limbah plastik yang digunakan pada penelitian berbentuk serpihan. Pencampuran agregat halus dengan serpihan limbah plastik ini juga bertujuan untuk memanfaatkan limbah yang dihasilkan agar tidak terbuang sia-sia. Hal ini tentu saja bermanfaat untuk mengurangi limbah yang ada.

Penelitian ini menitikberatkan pada pemakaian serpihan limbah plastik untuk mengurangi jumlah agregat halus yang digunakan. Persentase penggunaan limbah plastik terhadap agregat halus diatur pada batasan masalah pada subbab berikutnya. Dengan adanya penelitian ini diharapkan bisa menambah refrensi dalam alternatif penggunaan limbah sebagai bahan untuk timbunan ringan, dan diberi judul:Pemanfaatan Limbah Plastik sebagai Material Tambahan pada Konstruksi Timbunan Ringan

\section{Metode}

Penelitian ini dilakukan dengan metode eksperimen, yaitu melakukan percobaan dengan cara membuat benda uji. Penelitian yang dilakukan di Laboratorium Tanah Politeknik Negeri Malang ini menggunakan material berupa campuran tanah dan limbah plastik dengan komposisi sebesar $0 \%, 12,5$ $\%$, 22,5\%, dan 32,5\%. Pengujian yang dilakukan meliputi pengujian kadar air,berat jenis, berat isi, batas Atterberg, gradasi, pemadatan, dan CBR. Adapun alat yang digunakan dalam penelitian ini disesuaikan dengan pengujian yang dilakukan. Bahan penelitian berupa tanah di dapatkan di 
daerah Tumpang, Malang. Plastik PP yang dipakai berasal dari pabrik di daerah Singosari, Malang. Prosedur penelitian secara singkat dituangkan pada Gambar 1.

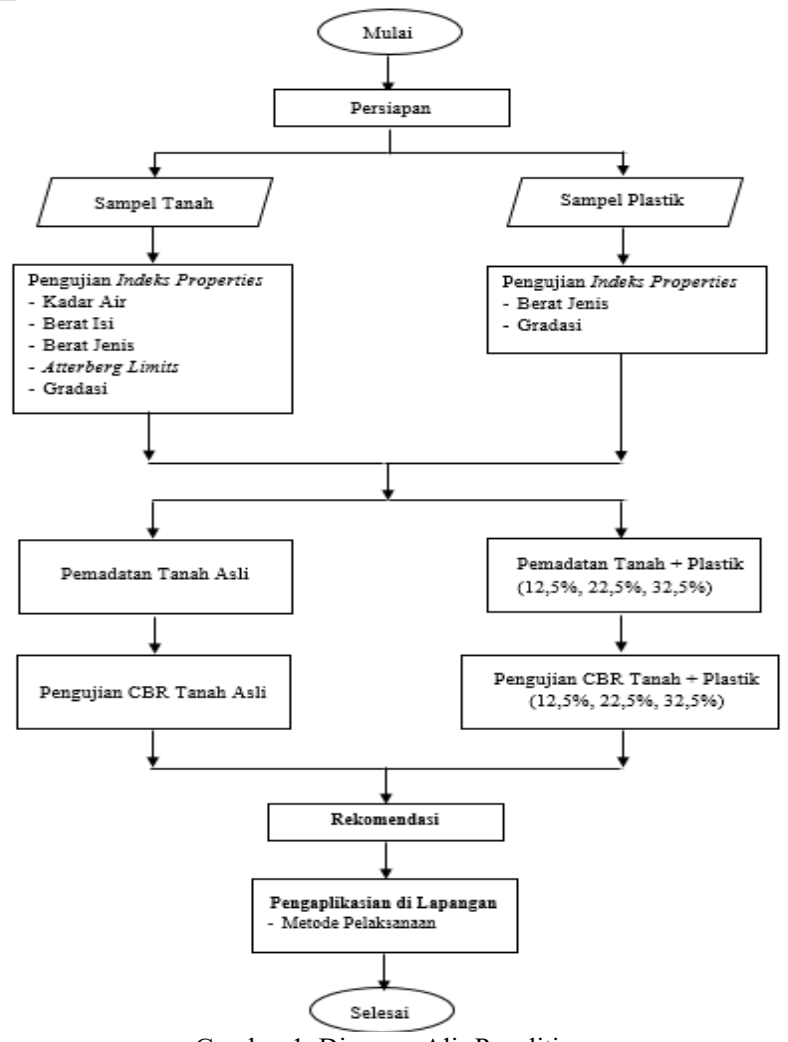

Gambar 1. Diagram Alir Penelitian

\section{A. Hasil dan Manfaat}

Berdasarkan pengamatan secara visual tanah asli di Desa Djago, Kecamatan Tumpang, Kabupaten Malang menunjukkan bahwa tanah tersebut berwarna coklat kemerah-merahan. Menurut pengujian laboratorium terkait karakteristik tanah, hasil pengujian direkapitulasikan pada Tabel 1.

\section{HASIL DAN PEMbahasan}

\section{A. Pengujian Pemadatan}

Pengujian pemadatan atau biasa disebut pengujian proctormeliputi pengujian pemadatan standarddan pengujian pemadatanmodified. Pada masing-masing komposisi, hasil pengujian pemadatan terdapat pada Tabel 2.

Tabel 2. Rekapitulasi Hasil Pengujian Pemadatan

\begin{tabular}{cccccc}
\hline \multirow{2}{*}{ No } & \multirow{2}{*}{$\begin{array}{c}\text { Komposisi } \\
(\%)\end{array}$} & \multicolumn{2}{c}{ MDD $\left(\mathrm{gr} / \mathrm{cm}^{3}\right)$} & \multicolumn{2}{c}{ OMC (\%) } \\
\cline { 3 - 6 } & & Standard & Modified & Standard & Modified \\
\hline 1 & 0 & 1,262 & 1,418 & 32,80 & 25,90 \\
2 & 12,5 & 1,152 & 1,294 & 36,40 & 28,60 \\
3 & 22,5 & 1,038 & 1,131 & 40,00 & 35,20 \\
4 & 32,5 & 0,840 & 0,912 & 46,50 & 41,10 \\
\hline
\end{tabular}

Sumber : Hasil Pengujian
Tabel 1. Karakteristik Tanah Asli

Parameter Pengujian Simbol Unit

\begin{tabular}{|c|c|c|c|}
\hline Kadar Air & $\mathrm{W}$ & $\%$ & 40,50 \\
\hline Berat Jenis & Gs & - & 2,55 \\
\hline Berat Isi & $\mathrm{y}$ & $\mathrm{gr} / \mathrm{cm}^{3}$ & 1,33 \\
\hline Butiran Lolos Ayakan No. 200 & - & $\%$ & 12,31 \\
\hline Batas Cair & LL & $\%$ & - \\
\hline Batas Plastis & PL & $\%$ & - \\
\hline Indeks Plastisitas & IP & $\%$ & - \\
\hline \multicolumn{4}{|l|}{ Klasifikasi Jenis Tanah: } \\
\hline Sistem USCS & - & - & SM \\
\hline Sistem AASHTO & - & - & $A-1-b$ \\
\hline \multicolumn{4}{|l|}{ Pemadatan Standard: } \\
\hline Kadar Air Optimum & $\mathrm{OMC}$ & $\%$ & 32,80 \\
\hline Kepadatan Kering Maksimum & MDD & $\mathrm{gr} / \mathrm{cm}^{3}$ & 1,262 \\
\hline \multicolumn{4}{|l|}{ Pemadatan Modified : } \\
\hline Kadar Air Optimum & $\mathrm{OMC}$ & $\%$ & 25,90 \\
\hline Kepadatan Kering Maksimum & MDD & $\mathrm{gr} / \mathrm{cm}^{3}$ & 1,418 \\
\hline \multicolumn{4}{|l|}{ CBR Unsoaked: } \\
\hline Standard & CBR & $\%$ & 17,73 \\
\hline Modified & CBR & $\%$ & 22,63 \\
\hline \multicolumn{4}{|l|}{ CBR Soaked: } \\
\hline Standard & $\mathrm{CBR}$ & $\%$ & 6,86 \\
\hline Modified & CBR & $\%$ & 11,97 \\
\hline
\end{tabular}

Sumber : Hasil Pengujian

Tabel 2 menunjukkan rekapitulasi hasil pengujian pemadatan pada komposisi campuran limbah plastik sebesar $0 \%, 12,5 \%, 22,5 \%$, dan 32,5\%. Data yang didapatkan berupa data kepadatan kering maksimum (MDD) dan data kadar air optimum (OMC).Hasil pengujian pemadatan yang ditinjau dari MDD dituangkan dalam bentuk grafik yang terdapat pada Gambar 1.

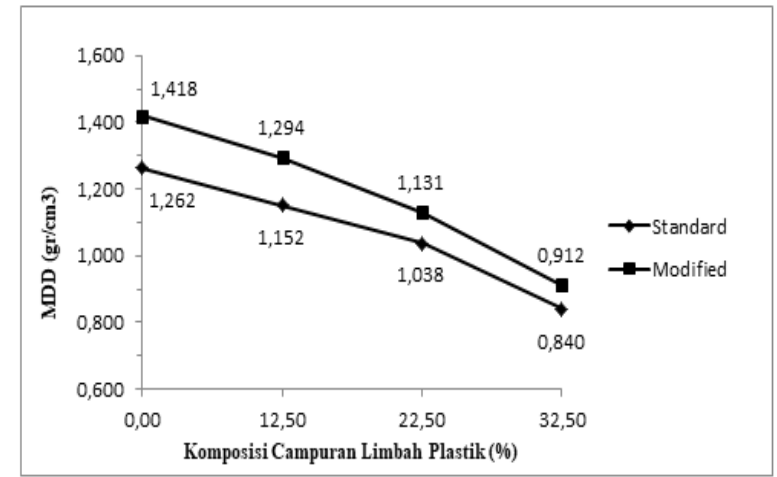

Gambar 1. Grafik Hubungan Komposisi Campuran Limbah Plastik dan MDD pada Pengujian Pemadatan Standard dan Modified

Gambar 1 menunjukkan grafik hubungan komposisi campuran limbah plastik dengan MDD pada pemadatan standard maupun modified. Semakin banyak komposisi campuran limbah plastik pada tanah maka dapat menyebabkan kepadatan tanah semakin menurun. Pada pemadatan standard, nilai MDD yang dihasilkan berturutturut pada komposisi $0 \%, 12,5 \%, 22,5 \%$, dan 32,5 \% yaitu sebesar $1,262 \mathrm{gr} / \mathrm{cm}^{3}, 1,152 \mathrm{gr} / \mathrm{cm}^{3}, 1,038 \mathrm{gr} / \mathrm{cm}^{3}$, dan 0,840 $\mathrm{gr} / \mathrm{cm}^{3}$. Pada komposisi campuran yang sama, nilai MDD pada pemadatan modified yakni sebesar $1,418 \mathrm{gr} / \mathrm{cm}^{3}, 1,294$ $\mathrm{gr} / \mathrm{cm}^{3}, 1,131 \mathrm{gr} / \mathrm{cm}^{3}$, dan $0,912 \mathrm{gr} / \mathrm{cm}^{3}$. Dari hasil tersebut dapat disimpulkan bahwa nilai MDD pada pemadatan 
modified lebih tinggi dibandingkan nilai MDD pada pemadatan standard.

Adapun hasil pengujian pemadatan selain ditinjau dari MDD, juga ditinjau dari OMC. Grafik hubungan komposisi campuran limbah plastik dengan OMC pada pemadatan standard maupun modified disajikan pada Gambar 2.

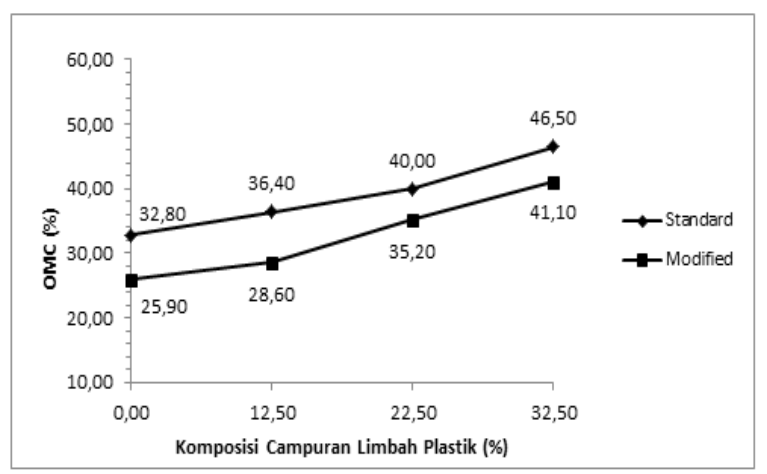

Gambar 2. Grafik Hubungan Komposisi Campuran Limbah Plastik dan OMC pada Pengujian Pemadatan Standard dan Modified

Gambar 2 menunjukkan bahwa semakin banyak komposisi campuran limbah plastik pada tanah maka kadar air optimum tanah semakin mengalami peningkatan. Pada pemadatan standard, nilai OMC yang dihasilkan berturutturut pada komposisi $0 \%, 12,5 \%, 22,5 \%$, dan 32,5 \% yaitu sebesar 32,80\%, 36,40\%, 40,00\%, dan 46,50\%. Pada komposisi campuran yang sama, nilai OMC pada pemadatan modified yakni sebesar 25,90\%, 28,60\%, 35,20\%, dan 41,10 $\%$. Dari hasil tersebut maka dapat disimpulkan bahwa nilai OMC pada pemadatan standard lebih tinggi daripada nilai OMC pada pemadatan modified.

\section{B. Hasil Pengujian CBR (California Bearing Ratio)}

Pada pengujian ini terdapat 2 jenis pengujian yang dilakukan yakni pengujian CBR standard dan pengujian CBR modified. Masing-masing pengujian CBR meliputi 2 jenis pengujian yaitu pengujian CBR soaked dan pengujian CBR unsoaked. Data yang didapatkan dari hasil pengujian CBR di laboratorium dituangkan pada Tabel 3.

Tabel 3. Rekapitulasi Hasil Pengujian CBR

\begin{tabular}{cccccc}
\hline \multirow{2}{*}{ No } & \multirow{2}{*}{$\begin{array}{c}\text { Komposisi } \\
(\%)\end{array}$} & \multicolumn{2}{c}{ CBR Standar } & \multicolumn{2}{c}{ CBR Modified } \\
\cline { 3 - 6 } & 0 & Unsoaked & Soaked & Unsoaked & Soaked \\
\hline 1 & 17,73 & 6,86 & 22,63 & 11,97 \\
2 & 12,5 & 13,53 & 5,13 & 18,31 & 10,49 \\
3 & 22,5 & 9,66 & 3,89 & 15,67 & 9,04 \\
4 & 32,5 & 7,76 & 2,69 & 10,93 & 8,14 \\
\hline
\end{tabular}

Sumber : Hasil Pengujian

Tabel 3 menyajikan data rekapitulasi hasil pengujian CBR pada komposisi campuran limbah plastik sebesar $0 \%$, $12,5 \%, 22,5 \%$, dan 32,5\%. Adapun hasil pengujian CBR berupa grafik hubungan komposisi campuran limbah plastik dan Nilai CBR pada pengujian CBR standard dan modified baik dalam kondisi soaked maupun unsoaked disajikan pada Gambar 3.

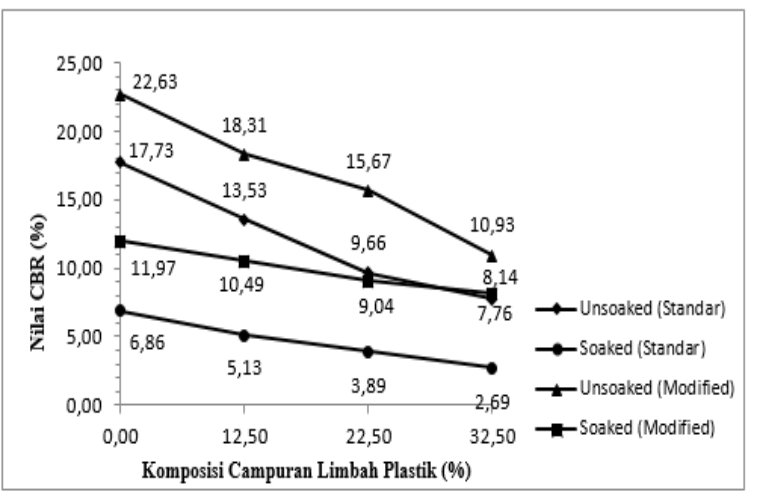

Gambar 3. Grafik Hubungan Komposisi Campuran Limbah Plastik dan Nilai CBR pada Pengujian CBR Standard dan Modified

Gambar 3 menjelaskan bahwa hasil pengujian CBR modified memiliki nilai CBR lebih tinggi dibandingkan pengujian CBR standar. Hal tersebut berlaku pada kondisi soaked dan unsoaked.

Adapun hasil pengujian CBR berupa grafik hubungan komposisi campuran limbah plastik dan Nilai CBR pada kondisi unsoaked disajikan pada Gambar 4.

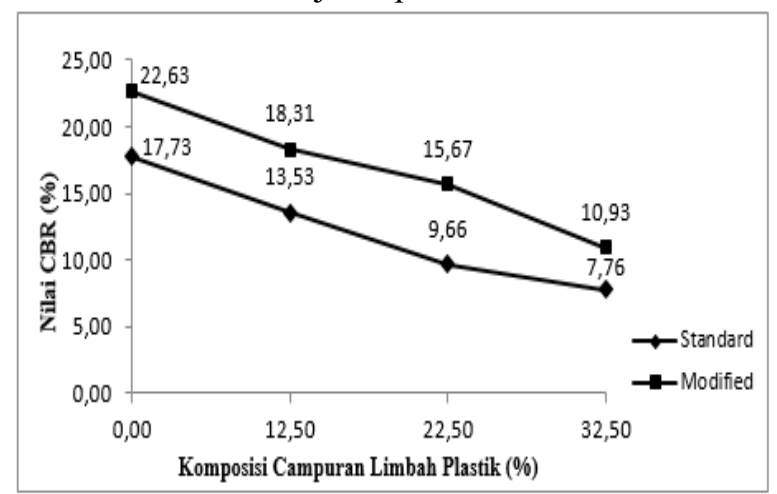

Gambar 4. Grafik Hubungan Komposisi Campuran Limbah Plastik dan Nilai CBR pada Kondisi Unsoaked

Gambar 4 menyajikan nilai CBR pada pengujian CBR standard sebesar $17,73 \%, 13,53 \%, 9,66 \%$, dan 7,76 \% pada komposisi campuran limbah plastik bertutut-turut sebesar 0 $\%$, 12,5 \%, 22,5 \%, dan 32,5\%. Pada pengujian CBR modified dengan komposisi campuran limbah plastik yang sama, dihasilkan nilai CBR sebesar 22,63\%, 18,31\%, 15,67 $\%$, dan 10,93 \%. Dari data tersebut dapat disimpulkan bahwa dalam kondisi unsoaked, pengujian CBR modified menghasilkan nilai CBR yang lebih tinggi daripada pengujian CBR standard.

Hasil pengujian CBR berupa grafik hubungan komposisi campuran limbah plastik dan Nilai CBR pada kondisi soaked disajikan pada Gambar 5. 


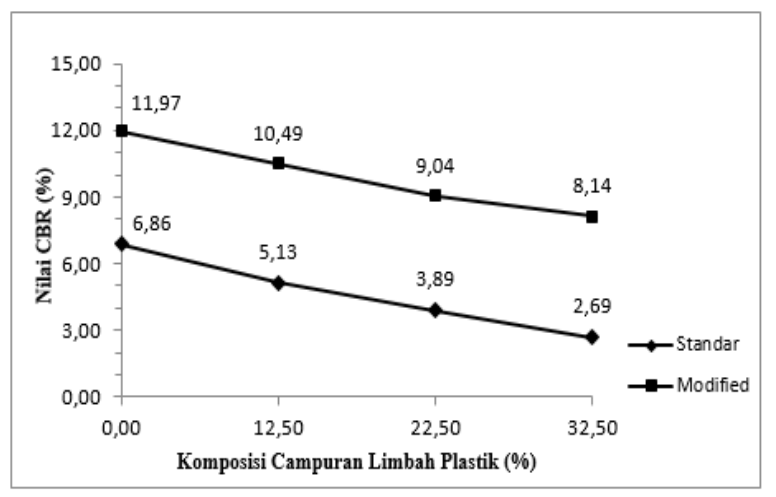

Gambar 5. Grafik Hubungan Komposisi Campuran

Limbah Plastik dan Nilai CBR pada Kondisi Soaked

Gambar 5 menunjukkan bahwa nilai CBR pada pengujian CBR standard pada komposisi campuran limbah plastik bertutut-turut yaitu $0 \%, 12,5 \%, 22,5 \%$, dan $32,5 \%$ sebesar $6,86 \%, 5,13 \%, 3,89 \%$, dan 2,69\%.Pada pengujian CBR modified dengan komposisi campuran limbah plastik yang sama, dihasilkan nilai CBR sebesar 11,97\%, 10,49\%, $9,04 \%$, dan 8,14 \%. Dari data tersebut dapat disimpulkan bahwa dalam kondisi soaked, pengujian CBR modified menghasilkan nilai CBR yang lebih tinggi daripada pengujian CBR standard.

Pengujian CBR yang telah dilakukan sekaligus sebagai salah satu tolak ukur untuk penggunaan limbah plastik sebagai material pengganti agregat halus pada timbunan. Dari hasil pengujian tersebut, direkomendasikan penggunaan komposisi campuran limbah plastik kurang dari 12,5\%. Sehingga apabila akan diaplikasikan di lapangan, maka sebaiknya dilakukan penelitian lebih lanjut dengan komposisi kurang dari $12,5 \%$. Penelitian ini di Adapun penelitian ini bisa diimplementasikan ke lapangan dengan prosedur yang sejenis dengan prosedur pekerjaan tanah pada umumnya. Yang membedakan dengan pekerjaan tanah secara umum hanya terdapat pada penggunaan motor grader untuk mencampur tanah dan limbah plastik tersebut. Adapun metode pekerjaan tanah yang dilakukan dapat dilihat pada Gambar 6.

\section{KESIMPULAN}

Berdasarkan hasil dari pembahasan, dapat disimpulkan sebagai berikut:

- Berdasarkan hasil pengujian laboratorium yang dilaksanakan, tanah asli digolongkan terhadap 2 jenis sistem klasifikasi yakni USCS (Unified Soil Classification Official) dengan hasil SM (pasir kelanauan) dan AASHTO (American Association of State Highway and Transportation Official) dengan hasil yang menyatakan bahwa tanah tersebut masuk pada golongan A-1-b. Hasil pengujian Atterberg menyebutkan bahwa tanah ini termasuk jenis tanah nonplastis (NP). Pengujian gradasi menyebutkan bahwa pada ayakan 2,00 mm, butiran tanah yang lolos sebesar $12,31 \%$. Butiran plastik Polyprophylene (PP) yang digunakan mayoritas lolos ayakan ukuran 4,75 $\mathrm{mm}$ dan tertahan pada ayakan ukuran 2,00 mm dengan pesentase sebesar 99,27 \%. Berat jenis tanah sebesar 2,55 lebih besar dibandingkan berat jenis plastik yaitu sebesar 0,80 .

- Limbah plastik yang dicampurkan pada tanah menyebabkan penurunan nilai CBR. Hal ini sesuai dengan hasil pengujian CBR standard persentase campuran limbah plastik $0 \%, 12,5 \%, 22,5 \%$, dan 32,5 $\%$ yang menghasilkan nilai CBR sebesar 17,73\%, 13,53 $\%$, 9,66 \%, dan 7,76 \% pada kondisi unsoaked. Sedangkan untuk kondisi soaked pada campuran limbah plastik yang sama, nilai CBR yang dihasilkan sebesar $6,86 \%, 5,13 \%, 3,89 \%$, dan 2,69\%. Ditinjau dari pengujian CBR modified, nilai CBR yang dihasilkan pada persentase campuran limbah plastik yang sama berturut-turut untuk kondisi unsoaked yaitu 22,63\%, $18,31 \%$, 15,67 \%, dan 10,93\%. Pada kondisi soaked dengan persentase campuran yang sama, nilai CBR berturut-turut sebesar $11,97 \%, 10,49 \%, 9,04 \%$, dan $8,14 \%$.

- Pengaplikasian material timbunan ringan kurang lebih sama dengan pekerjaan tanah pada umumnya. Yang membedakan yakni adanya proses pencampuran material limbah plastik tersebut dengan tanah menggunakan bantuan motor grader.

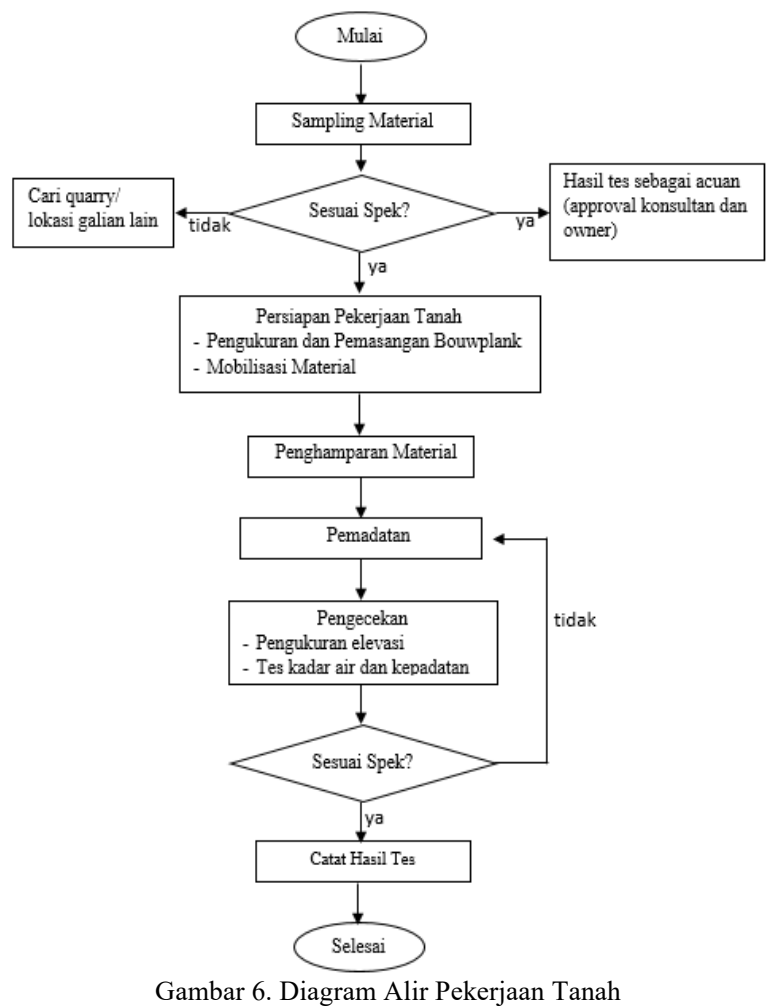

\section{DAFTAR RUJUKAN}

[1] Al-Huda, N., \& Gunawan, H. (2013). Pemanfaatan Limbah Karbit untuk Meningkatkan Nilai CBR Tanah Lempung Desa Cot Seunong. Konferensi Nasional Teknik Sipil (KoNTekS).7, hal. 151-156. Surakarta: Universitas Sebelas Maret (UNS).

[2] Andriani, dkk. (2012, Februari). Pengaruh Penggunaan Semen Sebagai Bahan Stabilisasi Pada Tanah Lempung Daerah Lambung Bukit Terhadap Nilai CBR Tanah. Jurnal Rekayasa Sipil, 8(1), 29-43.

[3] Aponno, G., \& Sholeh, M. (2012). Modul Ajar Laboratorium Uji Tanah. Malang: Politeknik Negeri Malang.

[4] Bowles, J. E., \& Hainim, J. K. (1993). Sifat-Sifat Fisis dan Geoteknis Tanah (Mekanika Tanah). Jakarta: Erlangga.

[5] Das, B. M. (1995). Mekanika Tanah (Prinsip-prinsip Rekayasa Geoteknis). Jakarta: Penerbit Erlangga.

[6] Hardiyatmo, H. C. (2011). Perencanaan Perkerasan Jalan dan Penyelidikan Tanah. Yogyakarta: Gajah Mada University Press. 
[7] Hendarsin, S. L. (2003). Penuntun Praktis Investigasi Rekayasa Geoteknik - Untuk Perencanaan Bangunan Teknik Sipil. Bandung: Politeknik Negeri Bandung.

[8] Luwalaga, J. G. (2016). Analysing the Behaviour of Soil Reinforced with Polyethylene Terephthalate (PET) Plastik Waste. Stellenbosch University, Engineering. Stellenbosch, South Africa: Stellenbosch University.

[9] Mujiarto, I. (2005, Desember). Sifat dan Karakteristik Material Plastik dan Bahan Aditif. Traksi, 3(2). 